\title{
GATT/WTO Membership and its Effect on Trade: Where Do We Stand? Andrew K. Rose*
}

\author{
Draft: June 3, 2009 \\ Preliminary: Comments Welcome \\ Please do not Quote without Permission!
}

\begin{abstract}
This paper reviews the recent literature that quantitatively assesses the effect on international trade of membership in the World Trade Organization (WTO) and its predecessor, the General Agreement on Tariffs and Trade (GATT). In my 2004a paper, I show that a straightforward look at the data does not find a strong effect of GATT/WTO membership on bilateral trade. I present and analyze three serious criticisms of this work: 1) inappropriate pooling of data across countries, sectors, and time; 2) inappropriate econometric techniques, especially regarding fixed effects; and 3) selection bias, since membership in the GATT/WTO may encourage pairs of countries to trade when they otherwise would not. I also present my critics with a couple of challenges, including finding a substantive effect of membership on multilateral trade and measures of trade policy.
\end{abstract}

Keywords: empirical, model, data, bilateral, gravity, multilateral, policy, international.

JEL Classification Numbers: F13

Contact: $\quad$ Andrew K. Rose, Haas School of Business, University of California, Berkeley, CA 94720-1900

Tel: (510) 642-6609

Fax: (510) 642-4700

E-mail: arose@haas.berkeley.edu

URL: http://faculty.haas.berkeley.edu/arose

* B.T. Rocca Jr. Professor of International Business, Economic Analysis and Policy Group, Haas School of Business at the University of California, Berkeley, NBER Research Associate, and CEPR Research Fellow. I thank Zdenek Drabek for comments and discussion. A current version of this paper is available at my website. This paper is closely based on my paper "The Effect of Membership in the GATT/WTO on Trade: Where Do We Stand?" 


\section{Introduction}

In 2002 I began to work on the effects of the World Trade Organization (WTO) and its predecessor the General Agreement on Tariffs and Trade (GATT). ${ }^{1}$ I was interested in quantifying the effects of membership in these multilateral trade organizations on international trade. I fully expected to find a large positive effect, and was primarily interested in comparing this to the effects of other things that enhanced trade (particularly the effects of currency unions). However, I was astonished to find that a naïve look at the data yielded little evidence that membership in the GATT/WTO had an effect on trade that was either economically or statistically substantive. In this paper, I review the state of the small literature that developed around this issue, as of April 2006.

\section{What I Did}

My initial (2004a) entrée used bilateral data to estimate the effect of membership in the GATT/WTO on trade. Since this paper has generated the most heat, it's worth explaining my methodology a little. I used a standard "gravity" model of bilateral trade augmented with additional controls:

$$
\ln \left(T_{i j t}\right)=\beta_{D} \ln D_{i j}+\beta_{Y} \ln \left(Y_{i} Y_{j}\right)_{t}+\beta_{X} X_{i j t}+\gamma_{1} \text { Bothin }_{i j t}+\gamma_{2} O_{\text {Onein }}{ }_{i j t}+\varepsilon_{i j t}
$$

where: the regressand (T) is (real) trade between countries $\mathrm{i}$ and $\mathrm{j}$ at year $\mathrm{t}, \mathrm{D}$ denotes great-circle distance between the countries, Y denotes real GDP, X denotes a vector of other controls (population, dummies for common language, money, and border, geographic characteristics, colonial characteristics, time dummies, and so forth), $\{\beta\}$ denotes a set of nuisance coefficients, 
and $\varepsilon$ is a (hopefully well-behaved) residual. The coefficients of interest to me were $\gamma_{1}$ (especially) and $\gamma_{2}$, which measure the effects on trade of GATT/WTO membership by both countries and one country respectively, ceteris paribus.

I estimated $\{\gamma\}$ in my benchmark regressions with OLS using a large panel of data covering over 50 years of data and 175 countries. To my surprise, I found that both coefficients were economically small and statistically insignificant (estimates are tabulated below). I also convinced myself that the results seemed to be insensitive to the exact econometric assumptions I made; more on that below. In passing, I also used multilateral data and event studies to verify the same points; more on that too, later.

For a while I didn't understand this negative result or think it plausible; it struck me as odd that membership in as apparently important an institution as the World Trade Organization could have a negligible impact on trade. But thanks to a moment of inspiration provided by my son, I realized that if GATT/WTO membership had little effect on trade policy, it might also have little effect on trade flows. ${ }^{2}$ Accordingly, I checked out this explanation in Rose (2004b). In that paper, I used almost 70 measures of trade policy and liberalization - all that I could find to see if membership in the GATT/WTO was actually associated with more liberal trade policy. With one exception - the Heritage Foundation's index of economic freedom - the answer was a resounding no; members of the GATT/WTO just didn't seem to have measurably more liberal trade policy than outsiders. This was consistent with my initial results on actual trade flows; it also seems to jive with the notions of many colleagues, as I discovered in subsequent presentations.

I also wrote two more narrowly focused follow-ups on the topic. Since some think that a big part of membership in the GATT/WTO is on the stability and predictability of trade policy, 
in Rose (2005a), I examined the second moment of trade flows, not their first moment. Again, I found little evidence of any large membership effect. In Rose (2005b), I compared the GATT/WTO with two other significant international institutions that are in the business of liberalizing trade, the International Monetary Fund and the Organization for Economic Cooperation and Development (OECD). I found that membership in the OECD had a consistently large positive effect while accession to (but not membership in) the GATT/WTO was also associated with increased trade. The latter effect stems from inclusion of country or country-pair specific fixed effects; more on that below.

In passing, I note that essentially all of the critiques to my work focus on my 2004a paper; no one, to the best of my knowledge, has investigated the follow-up papers. Too bad; to me, their consistency provides a reassuring part of the larger story.

\section{What I Didn't Do (and No One Can)}

I don't want to claim that the existence of the GATT/WTO has been irrelevant to trade or trade policy. No reasonable person could ever claim that, for a somewhat metaphysical reason. The GATT/WTO could have acted as an international provider of public goods in the form of providing global trade policy that is more liberal than it would have been in the absence of the system. One can never test this hypothesis, since we have only experienced (even in California) one history. Since there is no post-war span of time without the GATT/WTO, the counterfactual is not measurable; thus the basic idea cannot be tested or rejected. The GATT/WTO could have acted as a globo-cop, providing more liberal trade to all the world, independent of membership. This does not strike me as a plausible idea; why the fuss over e.g., China's accession to the WTO? In any case, since this topic is intrinsically untestable, I do not consider 
it to be interesting. Accordingly, the literature has stuck to a testable notion, namely the effect of membership in the GATT/WTO on trade. Since there's a lot of variation across both countries and time on this, estimating the effect of membership on trade is completely feasible.

\section{Quick Survey of the Preceding Literature}

\section{What Happened Afterwards}

(Skip the next paragraph if you don't enjoy shameless self-congratulation.) In the large, I have succeeded in my objective; there is now a small but growing body of scholarly research that investigates the impact of the international trade institutions on trade. Of course, it's early days, there's lots of dispute, and more remains to be done: as Evenett $(2005, \mathrm{p} 1)$ writes: "we know much less about the effects of WTO accession than we probably should... Generally, little is known about the effects of WTO accession on developing countries... The scholarly community is not alone in its lack of attention to WTO accession matters..." But at least we've started.

And a propos, I want to thank my critics. To have a critique published on your paper is a high honor. Only those who care, actually take the pains to work on a dispute.

\section{$\underline{\text { Reasons I Might Be Right }}$}

In the remainder of the paper, I will respond to my critics, organizing my thoughts by theme rather than paper. ${ }^{3}$ But before I go into defensive mode, let me lay out a few reasons why you might conceivably think I'm right, namely that membership in the GATT/WTO doesn't deliver more trade. These facts are mostly conventional wisdom that lie beyond the narrow confines of econometric estimates. 
1. Developing Countries. There's essentially universal agreement that the GATT historically made few demands on most countries in terms of trade liberalization, since most entrants were developing countries eligible for "special and differential treatment" (references are below). The GATT/WTO has always been a relatively toothless institution (by design), and has few levers to encourage liberalization. If accession to the GATT/WTO doesn't force countries to liberalize, why should one expect accession to have a measurable impact on trade? And if accession isn't the time when the GATT/WTO forced countries to liberalize, is the GATT/WTO really an effective agent of liberalization?

2. Sectors. The GATT/WTO has made almost no progress in liberalizing areas of great protectionism, such as agriculture and textiles.

3. MFN Status. Most Favored Nation (MFN) status might seem like the great prize of GATT/WTO membership. It turns out that MFN status is often given freely away. ${ }^{4}$

4. NTBs. Tariffs have been lowered by developed countries under the auspices of the GATT. But most are also well aware of the (deplorable) fact that non-tariff barriers have often been increased as substitute protectionism.

5. Liberalization and Accession. In the voluminous and controversial literature on trade and growth, no scholar, to my knowledge, has ever dated trade liberalization with GATT/WTO accession. (Sachs and Warner, for instance, tie liberalizations to the aftermath of macroeconomic crises.) If accession means liberalization and trade growth, why has no one ever tried to figure out if growth follows accession? Simple: liberalization dates have little to do with GATT/WTO accession. 
6. Ceteris Non Paribus. There are many other reasons why trade has grown, including declining transportation/communication costs, higher productivity growth in tradeables, and so forth.

\section{Phew: Replication}

I note in passing that a number of others have been able to confirm my benchmark

results. A quick tabulation of $\gamma_{1}$ coefficients estimated in a manner similar to (1) is presented in Table 1. A number of these are negative; none is significantly positive. The primary objective of a number of these projects was not the relevance of the GATT/WTO. For instance, Felbermayr and Kohler (2005) are primarily interested in resolving the "distance puzzle" of an elasticity of bilateral trade with respect to distance that seems to be increasing over time. ${ }^{5}$ Leeson (2005) is primarily interested in the importance of the New York Convention for trade. I conclude that plain vanilla estimation of the effect of GATT/WTO membership on bilateral trade does not deliver a large positive effect; one has to look more subtly for that result.

\section{$\underline{\text { Reasons I Might Be Wrong }}$}

There are three key criticisms of my work: inappropriate data pooling; inappropriate handling of fixed effects; and selection bias. Below, I summarize the arguments and respond. Then I present a few challenges to my opponents.

Piermartini and Teh (2005, pp 47-49) provide an alternative summary of different criticisms of my work. These include:

1. The fact that the GATT did not require significant reductions in trade barriers for developing countries acceding before the creation of the WTO in 1995, 
2. The fact that transition periods for tariff reductions are allowed,

3. The fact that many countries already benefited from MFN before accession,

4. The fact that many countries liberalized beforehand in order to facilitate accession,

5. The fact that LDCs often export fuels and minerals which face little protectionism (although agriculture, in which they have a comparative advantage, does)

6. The first five facts imply that the impact of membership should be higher in developed countries

They also summarize the work of others, especially Subramanian and Wei (2006), Tomz et al (2005), and the work of authors concerned with zero-trade observations. See also Evenett and Gage (2005), and Evenett, Gage, and Kennett (2004). I've collected some key estimates of the effect of GATT/WTO membership on trade in a table presented in the appendix.

\section{Criticism \#1: Excessive Pooling}

A number of my critics have argued that looking at all trade simultaneously masks the effects of the GATT/WTO. The fine work of Subramanian and Wei (2006) is especially forceful on this point. Their argument is that if you disentangle by country/time/sector etc, you can find significant trade effects of membership for subsets of the data. ${ }^{6}$ Subramanian and Wei show convincingly that different pieces of the data can certainly deliver significant and plausible effects of membership on trade.

This is certainly a serious critique, but I'm not sure it is a wholly legitimate argument. What do we learn when we study the trade patterns of countries and sectors that have liberalized, and ignore those that haven't? Subramanian and Wei claim that the GATT/WTO has been successful, since there has been liberalization by some countries in some sectors over some 
periods of time. Why can't one declare just as well failure since most countries have not liberalized most of their trade by now? To put it a different way the GATT has worked well, if you ignore the countries, sectors, and times when it hasn't. We're all agreed that if you ignore its failures, the GATT/WTO has been successful. But that's hardly a ringing endorsement of the institution.

\section{Pooling across Countries}

There are two critiques of relevance here, both associated with handling developing countries. The view of many, most notably Subramanian and Wei (2006), is that the GATT was essentially a club for developed countries. ${ }^{7}$ Subramanian and Wei argue that by including developing countries that are GATT members technically but not in spirit, I've rigged the analysis to make the GATT look irrelevant. Combining data on developing and developed countries masks the impact of the GATT on the latter. Their powerful conclusion is that the GATT/WTO has more than doubled global trade, much more than a statistical nicety.

On the other hand, Tomz et al. (2005) argue that some developing countries informally participated in the GATT and seemed to trade more than outsiders. Their statistical analysis relies on a carefully constructed data set that includes not only formal members of the GATT, but also a number of other categories for countries that participated in other capacities. Their argument is that I ignored these informal GATT participants, and thus under-estimated its impact. So while Subramanian and Wei criticize me for including any developing countries at all, Tomz et al say the opposite, which strikes me as odd, at least prima facie. Their view is that the relevance of the GATT can be rescued only by including developing countries, in particular 
those that aren't formally members but are in spirit. Both critiques are well-crafted and serious, but it's hard to see how they can both be right simultaneously. ${ }^{8}$

I prefer the Subramanian and Wei interpretation, since Tomz et al seem incongruous with the literature. ${ }^{9}$ Let me include a couple of typical excerpts that illustrate my discomfort. In Free Trade Agreements, Schott states (pp 9-10):

"Why are developing countries so interested in FTAs? In the past, these countries were able to obtain improved access to industrial markets through GATT negotiations that did not require them to reciprocate by opening their own markets to foreign competition. While useful, prior GATT rounds had two major shortcomings: they did not prompt policy changes in developing countries that would induce adequate flows of investment and transfers of technology (apart from extractive industries), and competitive agricultural and manufactured exports of developing countries often were excluded from the reforms. In short, developing countries were free riders on the GATT system until the Uruguay Round, but derived only modest benefits from their own minimal contributions to GATT negotiations. They protected their own markets, but in turn had to accept the maintenance of high foreign trade barriers against their most competitive exports."

Alternatively, Krueger writes in the introduction to The WTO as an International Organization

$(\mathrm{p} 7)$ :

“Developing countries' attitudes and trade policies during the 1950s and 1960s generally resulted in heightened walls of protection as industrialization through "import substitution" was attempted. That generally meant that developing countries were not benefiting as much as they might have from the growth of the world economy, while the "balance-of-payments" provisions of the GATT were liberally interpreted to enable developing countries to maintain quantitative restrictions, often including import prohibitions, on their imports. Moreover, the GATT articles were amended in the early 1960s to provide non-reciprocal preferential treatment of imports from those countries. One consequence was that developing countries (the East Asian newly industrializing countries being a prominent exception) were losing shares of their world markets."

It's worth stressing that developing countries really are key to Tomz et al. The second row of their Table 4 indicates that GATT participation has a statistically weak (though positive) effect on trade when you look only at industrial countries. The effect is significant only when you include developing countries. 
Another uncomfortable feature of the results of Tomz et al, is that informal participation in the GATT consistently matters more for trade than formal membership. This doesn't seem wholly plausible to me (at least not without some explanation), and is a cause for concern. I simply don't understand why informal participation could create more trade than actual membership in the GATT. This is especially true in light of the recent work by Tang and Wei (2006) who show that more rigorous entry requirements for WTO membership are associated with better results.

So I don't really buy the argument of Tomz et al that re-classifying certain developing countries as informal GATT participants can rescue the importance of the institution. That said, it seems inappropriate to ignore developing countries. There seems to be little doubt that the GATT made little impact on the trade policy of many developing countries. Personally, I think this cannot be counted as an indicator of the institution's success, so I guess I really just disagree with the interpretation of Subramanian and Wei (2006).

\section{$\underline{\text { Time and Industries }}$}

Just as Subramanian and Wei (2006) argue that I inappropriately bundle together developing and developed countries, they also argue that aggregating across sectors of economy can disguise the true effectiveness of the GATT/WTO. In particular, they argue that key sectors (critically agriculture, but also textiles, clothing and footwear) have not been included in the GATT's liberalization efforts, so that including these industries in the analysis gives a false impression that the institution has been ineffective.

Again, my interpretation is different. Agricultural produce is highly tradable, and has historically been the battleground for commercial policy. The beginning of the modern era of 
commercial policy is commonly considered to be the repeal of the British "Corn Laws" while the failure to liberalize agriculture remains a key reason why the Doha round has thus far met with limited success. If the GATT/WTO has been such a successful liberalizer, it does not seem kosher simply to ignore its failures in agriculture. ${ }^{10}$

On aggregation over time, I have little to say. I hope that the WTO (established to succeed the GATT in 1995) has been and will be a more effective liberalizer than the GATT.

Still, I haven't been able to see it myself in the data myself. ${ }^{11}$ Is China the new norm (and if it sticks to the spirit of its accession deal), or the exception? I think we need more time and more post-GATT accessions to resolve this issue. The preliminary evidence, as summarized in e.g., Ferrantino (2006) and Drabek and Bacchetta (2004) exists, but seems rather weak. Tang and Wei (2006) have found positive results of recent WTO entry on growth and investment, though they do not look directly at trade.

\section{Criticism \#2: Fixed Effects and Variation across Countries and Time}

A number of my critics note that most of my regressions do not include country-specific fixed effects in my gravity equations. When I did include them (in the first table of my paper!), the point estimate for the effect of joint membership in the GATT/WTO on trade was .15 (robust standard error of .05), implying that two countries inside the GATT/WTO trade about 16\% more, ceteris paribus. ${ }^{12}$ I dismissed this as "small compared to other effects (e.g., regional trade associations), the long-term growth of trade, intuition, and the hype surrounding the GATT/WTO.” That still seems right to me.

Many of my critics include fixed effects for either countries or country-pairs, thus using only time-series variation, the "within" estimator. They usually find significantly positive 
estimates of the effect of membership on trade. Since the within estimator doesn't use variation across countries, these estimates answer the question "What is the effect of accession to the GATT/WTO on trade ceteris paribus?" Hausman tests can be used to test the equality of the time-series within and cross-sectional "between" estimators. They typically reject equality of the two, so relying exclusively on OLS estimates (which assume equality) is statistically problematic. So while membership in the institution (which is partly a cross-sectional question) may not have a big positive effect on trade, joining it may (the latter is a time-series issue).

A couple of question in passing. Using the within estimator is tricky, since liberalization may not coincide with accession. There are at least two reasons, both well-known. First, countries may liberalize beforehand in order to facilitate accession. ${ }^{13}$ Second, joining members are often granted phase-ins so that liberalization may instead follow accession. A different issue altogether is whether the gravity model works well with fixed effects. Many coefficients change a lot when fixed effects are included. For instance, many of the GDP terms seem small. ${ }^{14}$

The more important question is how to interpret the evidence. I think we learn something from comparing the trade of members and non-members in the cross-section. That is, even if the within estimate is not equal to the between estimate, the latter should not be discarded. Crosssectional estimates often indicate a negative insignificant effect of GATT/WTO membership on trade. For instance, in my 2004a paper, I found the cross-sectional estimator of $\gamma_{1}$ to be -.50 (with a standard error of .21), while Tomz et al (2005) estimated it to be -.51 (.24). I have still not heard a good explanation of such findings is consistent with an important role for the GATT/WTO in stimulating trade. ${ }^{15}$

\section{Criticism \#3: Selection Bias}


In my 2004a paper, I followed the tradition in the field in essentially ignoring observations where there was no trade between a pair of countries. I reported some cursory Tobit estimates, but didn't really try to model or understand country-pairs with zero trade. That turns out to be a potentially serious issue if countries that belong to the GATT/WTO systematically trade with more countries than they otherwise would. That is, I didn't explicitly deal with the extensive margin of trade (whether a pair of countries trades at all), instead focusing on the intensive margin (that is, how non-zero trade varies across pairs of countries). Three papers have emerged since then that focus on this interesting and potentially important problem: Felbermayr and Kohler (2005), Helpman, Melitz and Rubinstein (2005), and Liu (2006). Each argues that members of the GATT/WTO have systematically more trading relationships, so that ignoring the effect of membership on the extensive trade margin leads one to under-estimate the impact of the GATT/WTO. This has been a fruitful insight and is a promising area of research. It has lead to a number of different econometric techniques for handling the intensive and extensive margins of trade simultaneously.

The reason why I basically ignored the zero trade observations wasn't silly, and is worth stating. My view was that missing regressor data (especially for GDP, which seemed vital for an empirical gravity model) was more important than censoring of the dependent variable. ${ }^{16}$ Now you can do without country-specific variables (such as GDP) in certain models; that's one of the nice features of Helpman et al. or any other technique that includes time-varying country-specific fixed effects. But for others working in the area, missing regressor observations seems to be an issue; e.g., Felbermayr and Kohler, and my original work.

Whether modeling the extensive margin of trade turns out to be important is unclear. If you add up the number of observations where a pair of countries actually trades and divide it by 
the number of potential bilateral trade relationships, you get a small number (e.g., Helpman et al show that only around half of all potential country-pairs actually trade). But that treats all trade relationships the same. If you weight by GDP or population, the ratios probably look much larger. Helpman et al $(2005$, p6) write “... the enlargement of the set of trading countries did not contribute in a major way to the growth of world trade." Liu (2006) disputes this conclusion, since he finds that much of the trade growth occurred between trading partners that did not trade in $1948 .{ }^{17}$ Currently, it's unclear to me just how important this issue is in practice.

There are at least a couple of other issues in the area. Some of the gravity effects estimated with the newer models seem like they've changed a lot, at least to me. It would also be interesting to see the effects of Tomz et al's informal participation combined with the careful selection bias techniques that have been developed.

Still, the GATT/WTO may well have played an important role in fostering the development of trade linkages that might not have existed in its absence. I expect further work on this issue in the future, but consider it to be a serious criticism of my initial analysis.

\section{Challenge \#1: Beyond Bilateral Trade Flows}

Many of my critics argue that the GATT/WTO has liberalized trade flows, if one looks carefully at bilateral data. Are these results apparent in multilateral data? My finding of a noneffect of GATT/WTO membership on trade seems to be apparent in the data, at least to me. In Rose (2004a) I presented both event studies and regression results that delivered basically the same result as my bilateral work. The question is: does GATT/WTO membership raise trade when we look at aggregate trade data appropriately? This is an interesting and important question that my critics have thus far not pursued (or at least not presented in print). 
To make this all a little more concrete, in Table 2 I present some multilateral results that have been taken from my 2004a paper. These examine the determinants of a country's trade with the rest of the world (rather than a country's trade with an individual trading partner, as in a bilateral gravity model). When I look at the results, I don't see any big impact of GATT/WTO membership on trade. ${ }^{18}$

In Figure 1 I also present a set of four event studies, similarly lifted from my 2004a paper. These examine aggregate openness - the ratio of export plus imports to GDP - around the dates of GATT/WTO entry. I show raw openness in the top-left graphic. The other three are analogous, but portray the residuals once openness has been regressed on the natural logarithms of both real GDP and real GDP per capita, and different fixed effects. Again, there is little evidence that GATT/WTO entry has a strong significant effect on the ratio of aggregate trade to GDP in any of the graphics.

Here's the first challenge to my critics: if the GATT/WTO matters, where's the evidence that it affects multilateral trade? Man does not live by the gravity model alone.

\section{Challenge \#2: Beyond Trade Flows}

If the GATT/WTO has liberalized trade, one might imagine that this should be visible in measures of trade policy as well as trade. Looking at the success of the GATT/WTO by relying completely on trade outcomes is problematic since there are many determinants of trade. It's difficult to measure trade policy, so one should be careful; but aren't more noisy indications of the GATT/WTO's success better than fewer? I analyzed trade policy in my (2004b) article and found almost no differences in a variety of measures of trade policy between GATT/WTO 
members and non-members. Again, I think it is incumbent on my critics to examine trade policy and show why my analysis is wrong or misleading. ${ }^{19}$

Table 3 shows the weak linkages between measures of trade policy and membership in the GATT/WTO. This is simply taken from my $2004 \mathrm{~b}$ paper; interested readers can refer to that paper for further details. I also present in Figure 2 some analogous event studies, again taken from my $2004 \mathrm{~b}$ paper. There is little evidence that GATT/WTO entry has a strong significant effect on trade policy.

My second challenge is: where's the convincing evidence that membership in the GATT/WTO has affected trade policy?

\section{Challenge \#3: What does the WTO Do?}

Until recently there has been something of a problem of understanding the basic rationale for the GATT/WTO. After all, the most primitive argument for trade liberalization is unilateral; why does one need a multilateral institution at all ${ }^{20}$

In an influential series of articles summarized in a monograph, Bagwell and Staiger (2003) have now provided an answer: negotiation through the GATT/WTO solves a terms of trade externality. Otherwise liberalizing countries might worry that unilateral elimination of protection might hurt their terms of trade.

This is a fine theoretical argument, and I admire and applaud the excellent work of Bagwell and Staiger. But is it of obvious empirical relevance? Thus far it has not been subjected to rigorous empirical analysis. Doing so is far beyond the scope of this paper, but let me provide a little evidence of relevance. In particular, I present in Figure 3 a set of plots that look at the World Bank's "barter terms of trade" (indexed so that they're all equal to 100 in the 
year 2000) during the three years before and after the completion of the Uruguay round. I do this on a country-by country basis, for twelve big economies, twelve OECD and four developing.

Now these graphics are rough. They're aggregate in that they cover the whole economy. Further, they're raw and a host of other features undoubtedly affected the terms of trade. One also doesn't know the counter-factual; how would the terms of trade be expected to move without the GATT/WTO? That is, it's not clear what the Bagwell-Staiger theory leads one to expect for the terms of trade. All that said, the terms of trade do not look particularly stable around the completion of the Uruguay round.

The analogous event study is presented in Figure 4. It pools data across all formal and de facto members of the GATT/WTO (using the Tomz et al membership data) and all four GATT rounds for which there are terms of trade data. The mean terms of trade is presented in between lines that delimit a confidence interval of $+/$ - two standard errors. It shows that there is typically an improvement of the terms of trade that is both economically and statistically significant. There is a striking amount of time-series variation of the terms of trade around the completion of GATT rounds.

I want to stress that this is the opposite of definitive empirical work. No other factors are taken into account, and it's not clear what the hypothesis of interest is. And this isn't a challenge to my critics; it's a challenge for anyone interested in understanding the GATT/WTO and the terms of trade. Still: is there evidence that membership in the GATT/WTO stabilizes or otherwise affects the behavior of the terms of trade?

\section{Final Notes}


There may be publication bias in this area of research. Publishing negative results is more difficult than positive ones. That's especially true in this context, since my 2004a paper simply presented a non-finding of a large effect of GATT/WTO membership on trade. People who find similar results may simply junk them; accordingly, researchers may be tempted to stretch their work towards finding positive conclusions.

I won't provide a conclusion. Personally, I still think the evidence of a strong positive effect of GATT/WTO membership on trade is lacking. I don't see its effects on aggregate trade or trade policy. That said, my initial pessimism about the impact of the institution has been tempered by the subsequent work. I find the work of especially Subramanian and Wei (2006) but also Tomz, Goldstein and Rivers (2005) relevant if not completely convincing. A more important gap in my initial work was the fact that I did not take the extensive margin seriously. I'm now persuaded that membership in the GATT/WTO encourages the creation of trading links where none might otherwise exist. How important this is to world trade and welfare is currently unclear to me; I look forward to more work in the area. 
Table 1: Replicating the Impact of Joint GATT/WTO Membership on Bilateral Trade

\begin{tabular}{|l|c|l|}
\hline Source & $\gamma_{\mathbf{1}}$ (se) & Notes \\
\hline Rose (2004a) & $-.04(.05)$ & Table 1, default \\
\hline Subramanian and Wei (2006) & $-.25(.04)$ & Imports, Table 6 col. 1 \\
\hline Tomz, Goldstein, and Rivers (2005) & $-.17(.03)$ & Table 2, col. 2 \\
\hline Liu (2006) & $-.08(.01)$ & Table 2, positive trade \\
\hline Felbermayr and Kohler (2005) & $.09(.08)$ & Table 2, intensive margin \\
\hline Leeson (2005) & $.12(.06)$ & Table 2, default \\
\hline Gowa and Kim (2006) & $.04(.03)$ & Table 1, col. 2. \\
\hline
\end{tabular}

Table 2: Aggregate Openness and the GATT/WTO

\begin{tabular}{|c|c|c|c|c|c|}
\hline & $\begin{array}{c}\text { Member of } \\
\text { GATT/WTO }\end{array}$ & $\begin{array}{l}\text { Log Real } \\
\text { GDP p/c }\end{array}$ & Log Pop & Remoteness & $\mathbf{R}^{2}$ \\
\hline & $\begin{array}{l}-.11 \\
(.02)\end{array}$ & & & & .12 \\
\hline & $\begin{array}{l}-.01 \\
(.01)\end{array}$ & $\begin{array}{c}.13 \\
(.01)\end{array}$ & $\begin{array}{c}-.22 \\
(.004)\end{array}$ & $\begin{array}{l}-1.86 \\
(.39)\end{array}$ & .53 \\
\hline With Extra Controls* & $\begin{array}{l}-.00 \\
(.01)\end{array}$ & $\begin{array}{l}.13 \\
(.01)\end{array}$ & $\begin{array}{c}-.16 \\
(.006)\end{array}$ & $\begin{array}{l}-.51 \\
(.44)\end{array}$ & .56 \\
\hline $\begin{array}{r}\text { Without year } \\
\text { Effects }\end{array}$ & $\begin{array}{l}-.01 \\
(.02)\end{array}$ & & & & .00 \\
\hline $\begin{array}{r}\text { Without year } \\
\text { Effects }\end{array}$ & $\begin{array}{c}.032 \\
(.014) \\
\end{array}$ & $\begin{array}{c}.16 \\
(.01)\end{array}$ & $\begin{array}{c}-.21 \\
(.003)\end{array}$ & $\begin{array}{l}-5.92 \\
(.34) \\
\end{array}$ & .47 \\
\hline Without year Effects, Extra Controls* & $\begin{array}{c}.006 \\
(.015)\end{array}$ & $\begin{array}{l}.15 \\
(.01)\end{array}$ & $\begin{array}{c}-.14 \\
(.006)\end{array}$ & $\begin{array}{l}-4.96 \\
(.39)\end{array}$ & .51 \\
\hline $\begin{array}{r}\text { Level of } \\
\text { Openness }\end{array}$ & $\begin{array}{l}-5.95 \\
(1.12)\end{array}$ & & & & .08 \\
\hline $\begin{array}{r}\text { Level of } \\
\text { Openness }\end{array}$ & $\begin{array}{l}-.21 \\
(.92)\end{array}$ & $\begin{array}{l}9.61 \\
(.52)\end{array}$ & $\begin{array}{c}-12.63 \\
(.26)\end{array}$ & $\begin{array}{c}82.5 \\
(33.2)\end{array}$ & .40 \\
\hline Level of Openness, Extra Controls* & $\begin{array}{c}-.58 \\
(1.01) \\
\end{array}$ & $\begin{array}{l}9.65 \\
(.50)\end{array}$ & $\begin{array}{l}-4.59 \\
(.59)\end{array}$ & $\begin{array}{l}243 \\
(36)\end{array}$ & .48 \\
\hline $\begin{array}{c}\text { Remoteness } \\
\text { using levels }\end{array}$ & $\begin{array}{l}.00 \\
(.01)\end{array}$ & $\begin{array}{l}.12 \\
(.01)\end{array}$ & $\begin{array}{c}-.22 \\
(.004)\end{array}$ & $\begin{array}{l}-1547 . \\
(390)\end{array}$ & .53 \\
\hline
\end{tabular}

Regressand: log of openness (i.e., ratio of exports plus imports to GDP in percent) unless noted.

Data from PWT6; 158 countries, 1950-1998; 5499 observations unless noted.

OLS with year effects (intercepts not reported).

Robust standard errors in parentheses.

* "Extra Controls" are: a) currency union dummy; b) dependency dummy; c) log of area; d) island dummy; and e) landlocked dummy. Extra controls reduce observations to 4803. 
Table 3: Trade Policy and GATT/WTO membership: Panel Measures

\begin{tabular}{|l|c|c|c|}
\hline & Bivariate & Augmented & IV \\
\hline Import Duties as \% & 2.1 & 1.8 & -45 \\
imports & $(1.7)$ & $(1.8)$ & $(.9)$ \\
\hline NBER Trade & .2 & -.5 & -2.7 \\
Liberalization Phase & $(.3)$ & $(1.0)$ & $(.3)$ \\
\hline Index Economic & -.0 & .0 & -4.6 \\
Freedom & $(.2)$ & $(.0)$ & $(1.7)$ \\
\hline Trade Policy Measure & -.7 & -.1 & -18 \\
from IEF & $(1.1)$ & $(.2)$ & $(1.6)$ \\
\hline Index from FX and & .00 & .00 & .26 \\
commercial policy & $(.0)$ & $(.1)$ & $(.6)$ \\
\hline Index from Tariffs and & .5 & $.4 *$ & -4.3 \\
NTBs & $(1.8)$ & $(2.0)$ & $(.4)$ \\
\hline Indirect counter- & .0002 & .0001 & .010 \\
agricultural bias & $(.6)$ & $(.4)$ & $(1.0)$ \\
\hline Gravity-Residuals, & -1.8 & -1.8 & -117 \\
basic model & $(1.8)$ & $(1.9)$ & $(.2)$ \\
\hline Gravity-Residuals, & -1.5 & -1.6 & -122 \\
augmented model & $(1.7)$ & $(1.7)$ & $(.3)$ \\
\hline Movement to & .01 & .01 & .06 \\
International Prices & $(.4)$ & $(.5)$ & $(.2)$ \\
\hline Modified Price & -.01 & -.01 & -3.4 \\
Distortion Index & $(.3)$ & $(.3)$ & $(1.5)$ \\
\hline Black Market Premium & -.26 & -.15 & -13 \\
& $(1.8)$ & $(1.5)$ & $(1.9)$ \\
\hline
\end{tabular}

Independent variable is membership in GATT/WTO.

Augmenting regressors: $\log ($ population $) ; \log ($ real GDP $\mathrm{p} / \mathrm{c})$; and remoteness.

Instrumental variable: Polity IV score of autocracy/democracy.

Absolute t-statistics (computed with standard errors robust to clustering by countries) in parentheses, except for IV estimates which use conventional standard errors.

** indicates significance at $1 \% ; *$ at $5 \%$.

Year and Country Fixed Effects included throughout. 
Figure 1: Effect of GATT/WTO entry on Aggregate Openness PWT6 data, 1950-98. Mean, with +/- 2 standard deviations. Regressions include logs of real GDP and real GDP p/c.
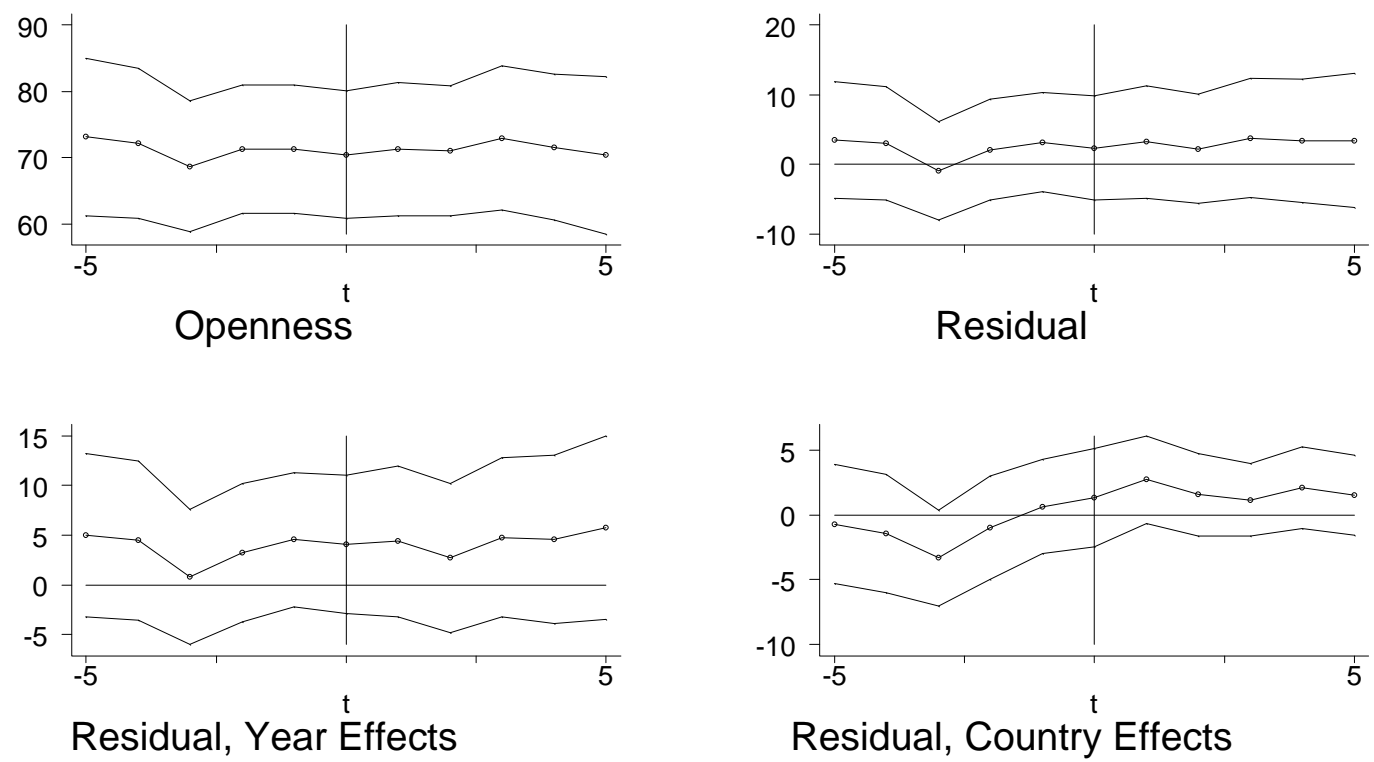

$+/-5$ years around entry of 104 countries Effect of GATT/WEO entry on Aggregate Openness, $(X+M) / Y$

\section{Figure 2: Effect of GATT/WTO Accession on Trade Policy}

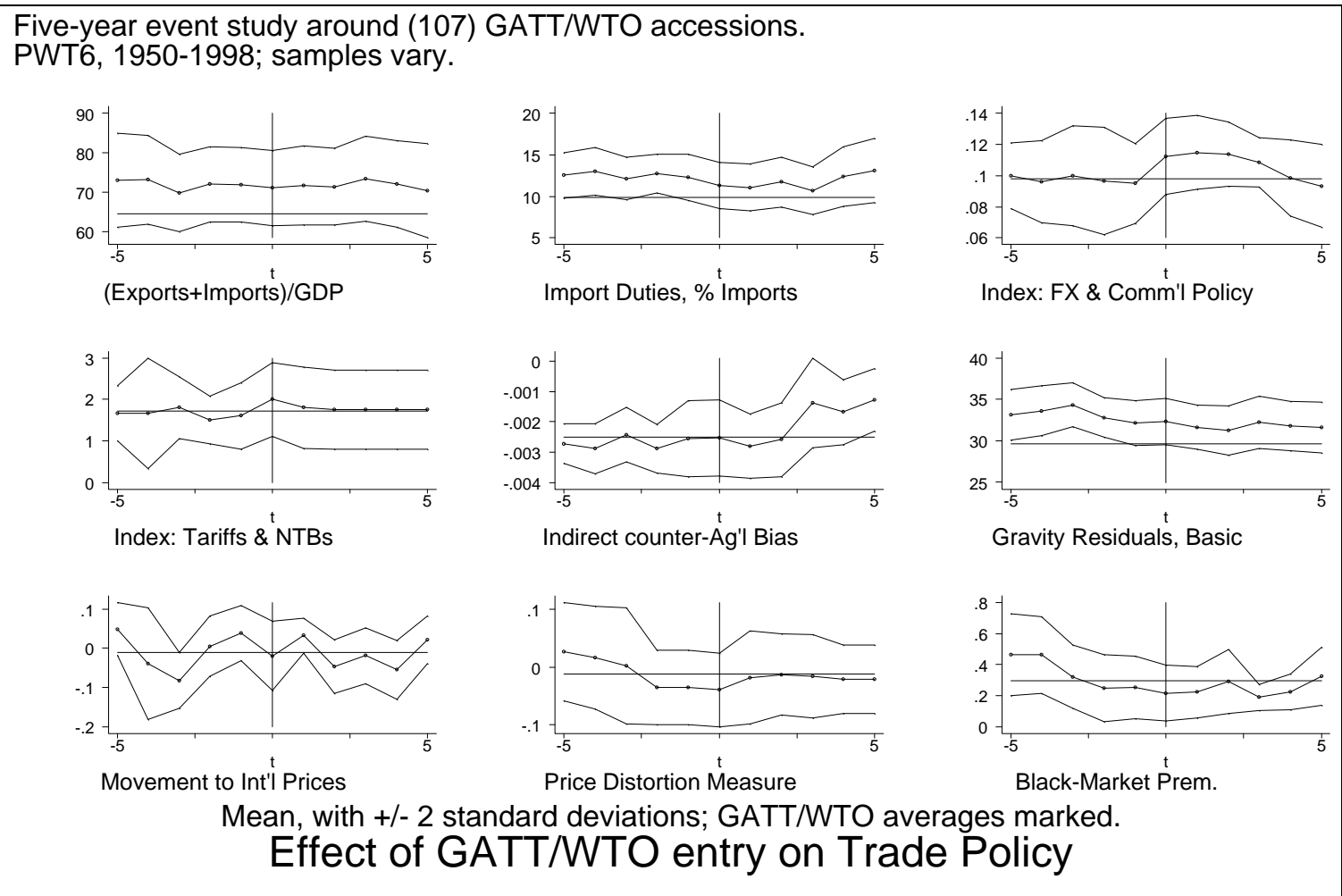


Figure 3: Terms of Trade around Completion of Final GATT Round
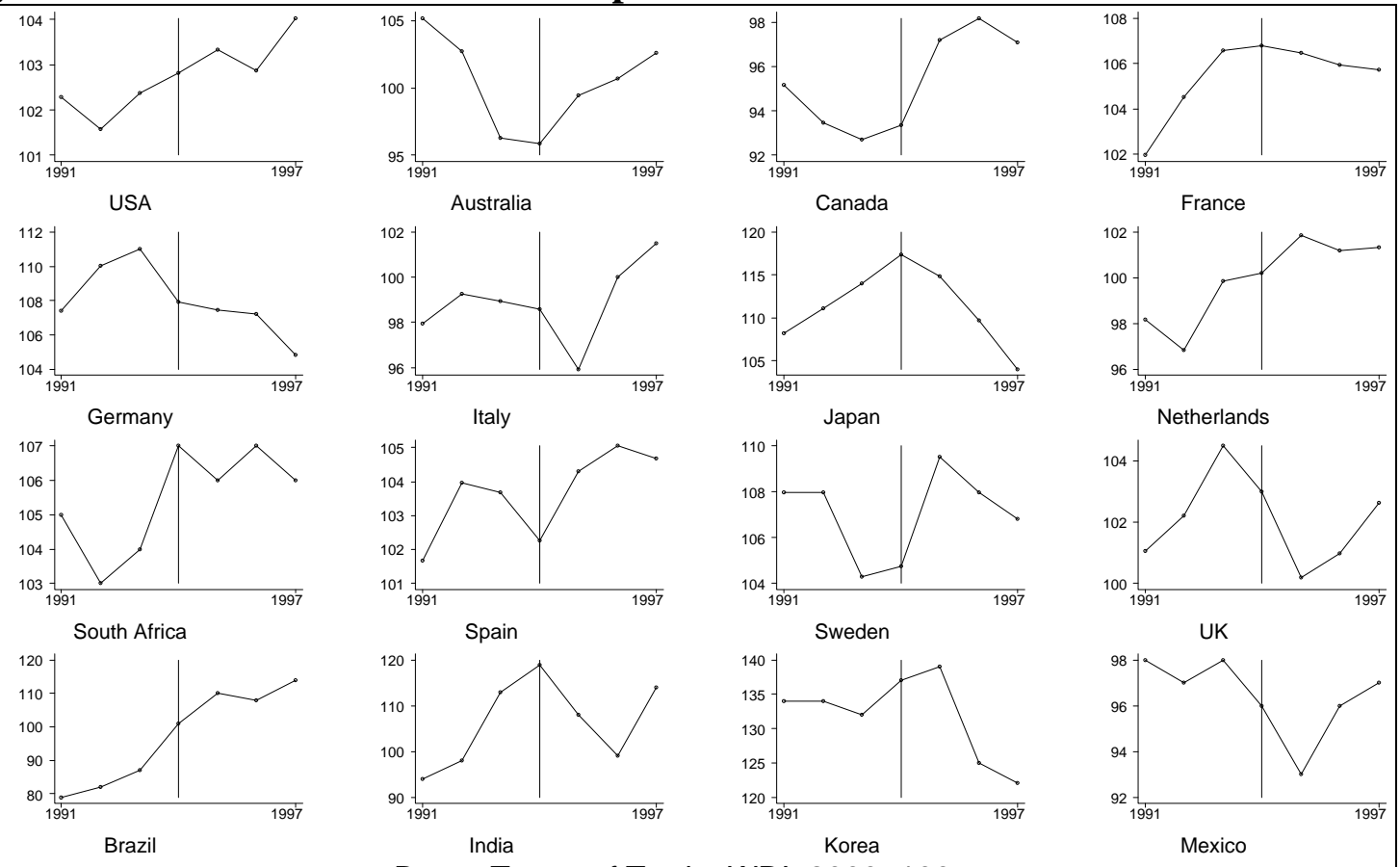

Terms of Trade around Uruguay Round Completion

Figure 4: Event Study on Terms of Trade and completion of GATT Rounds

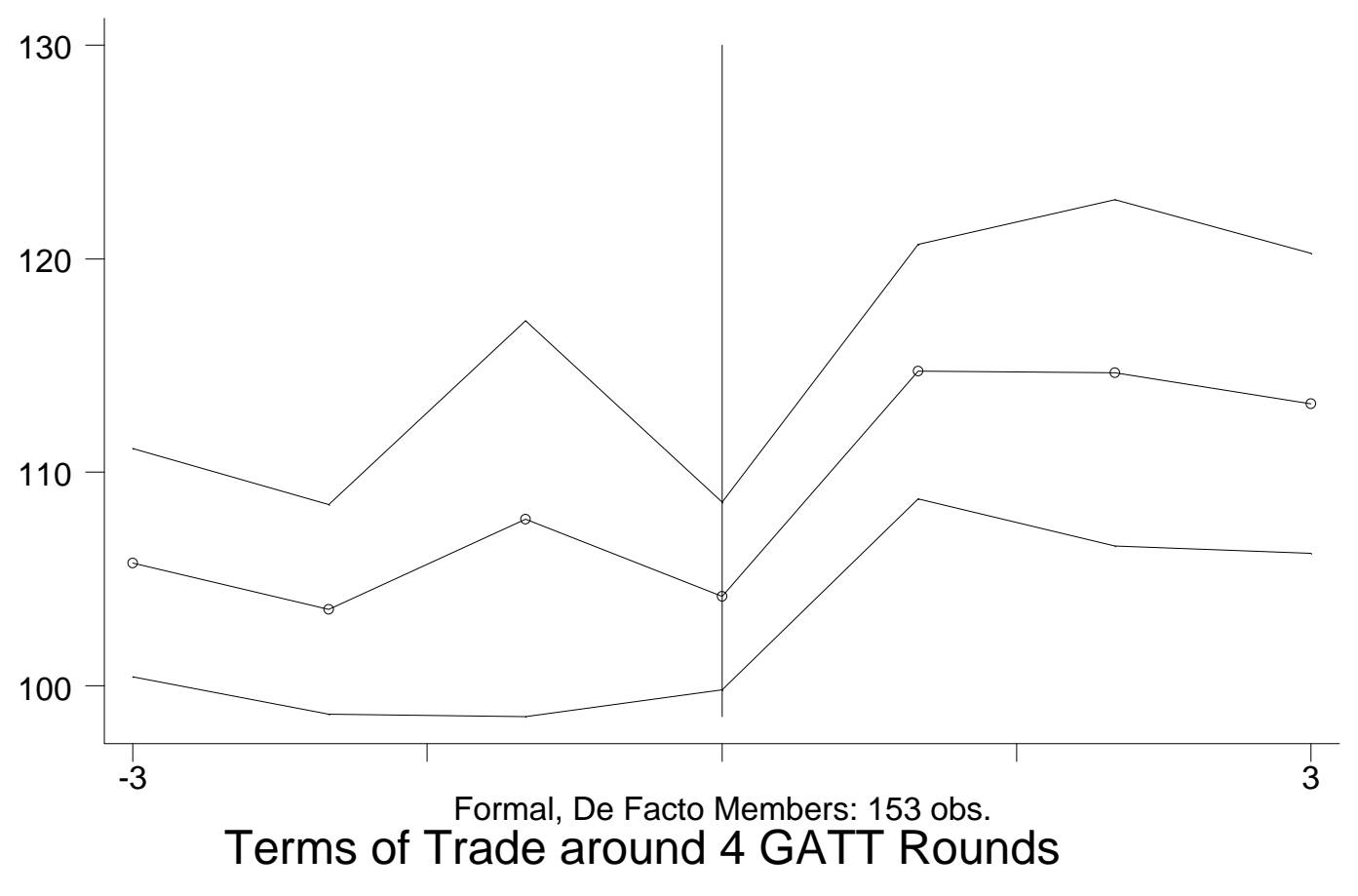


Table A1: Benchmark Estimates, Effect of GATT/WTO Membership on Bilateral Trade

\begin{tabular}{|c|c|c|c|c|c|}
\hline & No FE & $\begin{array}{c}\text { Country } \\
\text { FE }\end{array}$ & $\begin{array}{c}\text { Dyadic } \\
\text { FE }\end{array}$ & Other & Notes \\
\hline Rose (2004a) & $\begin{array}{l}-.04 \\
(.05)\end{array}$ & $\begin{array}{r}.15 \\
(.05 \\
\end{array}$ & $\begin{array}{c}.13 \\
(.02) \\
\end{array}$ & & \\
\hline Subramanian and Wei (2006) & & $\begin{array}{l}1.08 \\
(.10)\end{array}$ & & & Industrial Country Imports \\
\hline Tomz, Goldstein, and Rivers (2005) & $\begin{array}{c}.17 \\
(.07)\end{array}$ & $\begin{array}{c}.54 \\
(.06)\end{array}$ & $\begin{array}{c}.48 \\
(.06)\end{array}$ & & Formal Members \\
\hline Tomz, Goldstein, and Rivers (2005) & $\begin{array}{c}.80 \\
(.14) \\
\end{array}$ & $\begin{array}{c}.86 \\
(.12) \\
\end{array}$ & $\begin{array}{c}.88 \\
(.09) \\
\end{array}$ & & Nonmember Participants \\
\hline Liu (2006) & $\begin{array}{l}-.08 \\
(.01)\end{array}$ & & $\begin{array}{c}.04 \\
(.01)\end{array}$ & & Positive Imports \\
\hline Liu (2006) & $\begin{array}{l}2.09 \\
(.02)\end{array}$ & & $\begin{array}{l}1.45 \\
(.02)\end{array}$ & & All Imports \\
\hline Felbermayr and Kohler (2005) & & $\begin{array}{c}.09 \\
(.08)\end{array}$ & & & Positive Trade \\
\hline Felbermayr and Kohler (2005) & & $\begin{array}{c}.50 \\
(.09) \\
\end{array}$ & & & All Trade \\
\hline Helpman, Melitz, and Rubinstein (2005) & & $\begin{array}{c}.30 \\
(.04)\end{array}$ & & $.14(.04)$ & Other is ML \\
\hline Leeson (2005) & $.12(.06)$ & $\begin{array}{c}.13 \\
(.05)\end{array}$ & $\begin{array}{c}.13 \\
(.05)\end{array}$ & & \\
\hline Gowa and Kim (2006) & & & $\begin{array}{c}.04 \\
(.03)\end{array}$ & & \\
\hline
\end{tabular}

Estimates of $\gamma_{1}$ from regressions of type:

$$
\ln \left(\mathrm{T}_{\mathrm{ijt}}\right)=\beta_{1} \ln \mathrm{D}_{\mathrm{ij}}+\beta_{2} \ln \left(\mathrm{Y}_{\mathrm{i}} \mathrm{Y}_{\mathrm{j}}\right)_{\mathrm{t}}+\beta \mathrm{X}_{\mathrm{ijt}}+\gamma_{1} \text { Bothin }_{\mathrm{ijt}}+\gamma_{2} \text { Onein }_{\mathrm{ijt}}+\varepsilon_{\mathrm{ijt}}
$$

Standard Errors in parentheses.

Dyadic Fixed Effects refer to inclusion of country-pair specific fixed effects 


\section{References}

Bagwell, Kyle and Robert Staiger (2003) The Economics of the World Trading System (MIT: Cambridge).

Dam, Kenneth W. (1970) The GATT: Law and International Economic Organization (UC Press, Chicago).

Drabek, Zdenek and Marc Bacchetta (2004) "Tracing the Effects of WTO Accession on PolicyMaking in Sovereign States: Preliminary Lessons from the Recent Experience of Transition Countries" World Economy 27-7, 1083-1125.

Evenett, Simon J. (2005) "What is Known about the Effects of WTO Accession on Developing Countries?" unpublished, Brookings.

Evenett, Simon J., Jonathan Gage and Maxine Kennett (2004) "WTO Membership and Market Access" unpublished, Brookings.

Evenett, Simon J. and Jonathan Gage (2005) "Evaluating WTO Accessions" unpublished, Oxford University.

Felbermayr, Gabriel J. and Wilhelm Kohler (2005) "Exploring the Intensive and Extensive Margins of World Trade" unpublished, Tübingen University.

Ferrantino, Michael J. (2006) "Policy Anchors: Do Free Trade Agreements Serve as Vehicles for Developing Country Policy Reform?” unpublished, USITC.

Gowa, Joanne and Soo Yeong Kim (2006) "An Exclusive Country Club: The Effects of the GATT on Trade, 1950-94" unpublished, Princeton University.

Helpman, Elhanan, Marc Melitz and Yona Rubinstein (2005) “Trading Partners and Trading Volumes" unpublished, Harvard University.

Leeson, Peter T. (2005) "How Important is State Enforcement for Trade?" unpublished, George Mason University.

Lissovolik, Bogdan and Yaroslav Lissovolik (2004) "Russia and the WTO" IMF working paper WP/04/159.

Li, David D. and Changqi Wu (2004) "GATT/WTO Accession and Productivity" in Growth and Productivity in East Asia (Ito and Rose, eds. University of Chicago Press).

Liu, Xuepeng (2006) “GATT/WTO Promotes Trade Strongly: Solving the Sample Selection Bias" unpublished, Syracuse University. 
Piermartini, Roberta and Robert Teh (2005) "Demystifying Modelling Methods for Trade Policy" WTO Discussion Paper No. 10.

Rose, Andrew K. (2004a) "Do We Really Know that the WTO Increases Trade?" American Economic Review.

Rose, Andrew K. (2004b) “Do WTO Members have More Liberal Trade Policy?” Journal of International Economics.

Rose, Andrew M. (2004c) "Response to Subramanian and Wei” unpublished, UC Berkeley.

Rose, Andrew K. (2005a) “Does the WTO Make Trade More Stable?” Open Economies Review.

Rose, Andrew K. (2005b) "Response to Tomz, Goldstein and Rivers" unpublished, UC Berkeley.

Rose, Andrew K. (2005c) "Which International Institutions Promote International Trade?" Review of International Economics.

Subramanian, Arvind and Shang-Jin Wei (2006) "The WTO Promotes Trade, Strongly but Unevenly" unpublished, IMF.

Tang, Man-Keung and Shang-Jin Wei (2006) "Is Bitter Medicine Good for You? The Economic Consequences of WTO/GATT Accessions" unpublished, IMF.

Tomz, Michael, Judith Goldstein and Douglas Rivers (2005) "Membership has its Privileges: The Impact of GATT on International Trade" unpublished, Stanford University. 


\section{Endnotes}

${ }^{1}$ My inspiration came from $\mathrm{Li}$ and $\mathrm{Wu}(2004)$.

${ }^{2}$ The story is entertaining, and revolves around a trip I took with my family from San Francisco to Singapore. We had to stop for couple of hours in Hong Kong to change planes, and my wife and I gave our son Asher (who happened to be turning three that day) the choice of either playing at the airport playground or going to one of the lounges (as a United Premier Executive, he was entitled to the Gold lounge even at age two). He wisely chose the playground and I got to watch him while Miriam went to the lounge. He played, ran, shouted, and let off steam while I tried (and again failed) to figure out why I couldn't find any effect of GATT/WTO membership on trade. After a while, Asher told me that he'd had enough and wanted to go to the lounge. Fine, I explained, but in the lounge you have to be calm, quiet, orderly and so forth. He agreed. We went to the lounge and sure enough, he went wild as soon as we got in, tearing around, yelling and having fun (as three-year olds do). I reminded him that we'd agreed to a deal, and he was supposed to shape up when we entered the lounge. "Yes," he said to me, "but now I'm in."

${ }^{3}$ My responses to two significant critiques - Tomz, Goldstein, and Rivers (2005) and Subramanian and Wei (2006) - are available on my website as Rose (2005b) and (2004c) respectively. I borrow from them freely in what follows.

${ }^{4}$ For instance, in 2003 only four countries (Cuba, Laos, North Korea, and Serbia) did not have normal trade relations (the equivalent of MFN status) with the United States, even though many countries were not in the WTO (Russia and Saudi Arabia being perhaps the most prominent non-members). Symmetrically, WTO incumbents have not always extended MFN status to acceding countries; Drabek and Bacchetta (2004, pp 1094-95).

${ }^{5}$ Gowa and Kim (2006) are concerned to "show that the GATT had a large, positive, and significant impact on trade between only five of its member states: Britain, Canada, France, Germany, and the United States." They note that "When Japan acceded to the GATT in 1955, more than 40 percent of its members denied it MFN treatment in order to protect their markets against a flood of textiles and other labor-intensive products in which Japan held a comparative advantage ..." and find that policy towards Italy was similar. They also argue that goods were defined so narrowly that gods were defined so narrowly that most concessions were essentially bilateral, not multilateral. For instance, they state (Gowa and Kim, p11):

"As in the interwar era, however, the products on which tariffs were cut were defined as narrowly as possible in an effort to restrict their benefits to a single country. In 1948, for example, when the United States reduced its tariff on feldspar china, it simultaneously added "value brackets" to its tariff schedule, making the new rate applicable "only to plates, cups, saucers and other items valued at more than specified amounts." This precluded their application to the "bulk" of Japanese imports. That very few products appear on the concessions list of more than one pair of countries also attests to efforts to privatize tariff cuts. During the 1955-56 trade round, for example, the United States cut its tariff on a total of 59 imports from Britain, Canada, France, and Germany. With one exception, no concession seems to have applied to a good produced by more than one of these countries."

${ }^{6} \mathrm{I}$ did cut the data in over forty different ways in the original paper, but obviously I may have missed the right way.

${ }^{7}$ Tang and Wei $(2006, \mathrm{p} 3)$ state "In the first four decades of the GATT, developing countries were not asked to do much reform if they wanted to join the club. Indeed, many of them retained very high bound tariff rates even after becoming GATT members."

${ }^{8}$ The criticism of Tomz et al (2005) is not inappropriate pooling, but measurement error in my GATT/WTO membership variable.

${ }^{9}$ Tomz et al $(2005$, p6) write "De facto participants were 'expected to observe the substantive provisions of the General Agreement.' But they had fewer administrative responsibilities than formal members ... De facto participants received MFN treatment, were invited to participate in multilateral trade negotiations, and could observe the annual GATT sessions." By way of contrast Tang and Wei (2006, p5) state "Up to the end of 1994, a subset of developing countries were eligible to join the GATT under article XXVI 5(c) by essentially sending a notification to the GATT without having to promise reforms."

${ }^{10}$ There is little doubt that the GATT/WTO has failed in this area. Consider Dam (1970, pp 257-8) who states "It would be difficult to conclude that the GATT's record in the sphere of temperate agriculture commodities is other than one of failure ... [Agricultural protectionism, especially NTBs] cannot be justified under the provisions of the General Agreement ... there can be little doubt that few of the nontariff barriers on imports of agricultural commodities can be justified under ... special dispensations." 
${ }^{11}$ In my (2004a) paper, I found that $\gamma_{1}$ tended to fall in the last part during the WTO era; e.g., Tables 2 and 3; Tomz et al (2005) find comparable results in their Tables 3 and 5.

${ }^{12}$ In passing: in my 2004a paper, I included only one set of bilateral estimates with country-specific fixed effects, but over a dozen with country-pair-specific ("dyadic") fixed effects. These take into account not multilateral "trade resistance" and other unobservable features of individual countries, but trade resistance (and other unobservable features) of the relationship between each pair of countries. This seems much more general.

${ }^{13}$ Ferrantino (2006) analyzes liberalization during the run up to recent WTO accessions and American FTAs. He notes the long lags between a country's initial application for WTO membership and its actual accession.

${ }^{14}$ Thus e.g., the log product real GDP term falls from .93 (standard error of .01) in column 3 of Table 2 of Tomz et al to $.18(.05)$ when country fixed effects are added and $.47(.05)$ when dyadic fixed effects are added in columns 4 and 5 .

${ }^{15}$ In fact the problem may be worse, since countries are naturally open to international trade may tend disproportionately to join. This biases the cross-sectional coefficient upwards, making it especially likely to be positive. But it's been found to be negative, by both me and my critics.

${ }^{16}$ Usually when you're missing data to model trade between the United States and Bongo-Bongo it's not the trade data that's missing (or zero), but GDP.

${ }^{17}$ However, it is unclear whether this growth occurred because of the appearance of new countries, or because countries that exited in 1948 chose not to trade then but did trade afterwards; see also Felbermayr and Kohler (2005).

${ }^{18}$ This is consistent with Drabek and Bacchetta (2004, pp 1092-93), who find that recently countries "have been able to negotiate the terms of their WTO accession within the scope of measures already taken..." so that "almost all countries in our sample actually applied lower tariffs than those bound in the WTO." They later conclude (p 1105) that "very little" of the tariff decline was brought about by accession to the WTO.

${ }^{19}$ Ferrantino (2006, p21) writes "The ongoing WTO accessions, in fact, show more cases of deterioration than improvement in five of the six indicators [of national governance], showing a balance of improvement only for "government effectiveness." This is not encouraging, as it suggests only more efficient repression and corruption." Later on (p22) he writes "In 10 out of the 11 cases of a change in score associated with WTO accession the [trade] score [of the heritage Foundations Index of Economic Freedom] in fact declines."

${ }^{20}$ Drabek and Bacchetta (2004) provide a number of other reasons for joining the WTO, but these do not seem particularly compelling to me, since they do not seem intrinsically international. For instance, they argue (pp 108991) that WTO membership enhances the credibility of both domestic and foreign governments' policy. But domestic institutions are almost always more important and credible than international commitments. 